\title{
AKUNTABILITAS PELAYANAN PUBLIK DI KANTOR CAMAT DUSUN TENGAH KABUPATEN BARITO TIMUR
}

\author{
Herry Christiadi
}

\begin{abstract}
ABSTRAK
Akuntabilitas pelayanan publik, dimana pemerintah ada untuk melayani masyarakat, sehingga kantor kecamatan dijadikan sebagai pusat pelayanan publik, yang diharapkan bisa memberi rasa puas kepada publik dalam proses pemerintahan. Kepuasan publik akan terpenuhi apabila pelayanan yang diberikan sesuai dengan harapan.

Metode yang peneliti gunakan untuk mengetahui bagaimana akuntabilitas pelayanan publik yaitu deskriptif dengan metode pendekatan kualitatif. Sumber data terdiri dari data primer dan data sekunder yang diperoleh dari hasil observasi, wawancara dan dokumentasi dan data tersebut kemudian diolah dan dianalisis.

Demi terciptanya akuntabilitas pelayanan publik, maka dalam suatu pelayanan yang sangat menyangkut kepentingan publik diharapkan akan diselenggarakan sesuai dengan aturan-aturan yang diterapkan. Oleh karena ruanglingkup akuntabilitas pelayanan publik yang diberikan tidak hanya kepada informal dengan ruanglingkup organisasi saja akan tetapi juga pada eksternal organisasi dengan kata lain kepada masyarakat dan pihak lainnya yang berkepentingan.
\end{abstract}

\section{Kata Kunci : Akuntabilitas Pelayanan Publik.}

\section{PENDAHULUAN}

\section{Latar Belakang}

Dalam rangka mencapai tujuan dan aspirasi mayarakat, setiap negara harus memiliki suatu penyelengaraan kepemerintahan yang baik. Untuk mencapai kepemerintahan yang baik tersebut harus dimulai dari terwujudnya good governance.

Terkait dengan konsep good governance, dalam prakteknya aparat kecamatan dituntut untuk dapat mempertanggungjawabkan atas kewenangan yang diembannya. Dalam hal mempertanggungjawabkan kewenangannya inilah aparat pemerintah dituntut untuk menjalankan azas-azas akuntabilitas kinerja. Hal ini bertujuan karena pemerintah ditingkat kecamatan merupakan aktor utama dalam menjalankan fungi-fungi pokok pemerintahan. Oleh karena itu, menjadi kewajiban seseorang atau badan hukum atau pimpinan uatu organisasi untuk mempertanggungjawabkan dan menjelaskan kinerja atau tindakannya kepada pihak-pihak yang mempunyai hak untuk meminta jawaban serta penjelasan ata hasil seluruh tindakannya.

Maka dari itu dapatlah kita lihat bahwa tujuan dibuatnya sistem akuntabilitas adalah untuk mendorong terciptanya akuntabilitas kinerja instansi pemerintahan yang baik dan dipercaya. Hal ini secara langsung dapat mendukung terbentuknya kinerja pegawai yang akuntabel, efisien, efektif, responsif sehingga terciptanya tata pemerintahan yang baik yang dapat meningkatkan kepercayaan masyarakat sebagai pihak yang menerima pelayanan publik. 
Seperti yang kita ketahui selama ini didalam kecamatan dusun tengah saat ini, bahwa kinerja pegawai dalam organisasi pemerintah sangatlah buruk, dimana banyak sekali pemborosan biaya dengan adanya unsur-unsur korupsi dalam tubuh birokrasi kita saat ini. Struktur organisasi pemerintahan yang telah dibangun secara hirarki fungsional pada saat ini dengan digerakan oleh peraturan-peraturan yang kaku sering kali tidak menciptakan iklim yang kondusif bagi peningkatan kinerja organisasi dalam pemberian pelayanan publik.

Oleh karena itu, semenjak dikeluarkannya undang-undang yang mengatur pemerintah daerah, pemerintah daerah dituntut untuk berusaha meningkatkan pelayanan publik. Tantangan yang akan dihadapi oleh pelayanan publik adalah bukan hanya menciptakan pelayanan yang efisien, namun juga bagaimana pelayanan juga dapat dilakukan tanpa membeda-bedakan status dari masyarakat yang dilayani atau dengan kata lain bagaimana menciptakan suatu pelayanan yang adil dan demokratis.

Menilai kualitas pelayanan publik sangatlah diperlukan bagi pengguna jasa pelayanan termasuk tingkat kesulitan atau kemudahannya mengenai karakteristik pelayanan yang telah diberikan. Cara mengukur indikator kinerja sangatlah menentukan apakah suatu organisasi publik dapat dikatakan berhasil atau tidak, sehingga ketepatan pengukuran kinerja sangat menentukan penilaian akhir kinerja. Pengukuran kinerja merupakan jembatan antara perencanaan strategis dan akuntabilitas, sehingga uatu pemerintah daerah dapat dilakukan berhasil jika terdapat bukti-bukti atau indikator atau ukuran capaian yang mengarah pada pencapaian misi.

Dalam hal ini perlu dilihat praktek-praktek yang dibangun oleh pihak-pihak yang berkepentingan dengan pelayanan publik untuk menjamin tingkat kinerja yang telah diinginkan. Karena dalam organisasi publik, akuntabilitas berarti suatu perwujudan kewajiban untuk mempertanggungjawabkan keberhailan visi dan misi maupun strategis pelaksanaan dalam organisasi publik yang bersangkutan dalam mencapai tujuan dan sasaran yang telah ditetapkan melalui media pertanggungjawaban yang dilaksanakan secara periodik.

Dengan adanya akuntabilitas maka diharapkan kinerja pegawai dapat meningkat. Karena dalam akuntabilitas, pegawai dihadapkan pada kewajiban yang harus dilaksanakan secara benar dan baik. Dengan adanya seperti itu maka jika dilihat dari posisinya, suatu kecamatan memiliki posisi yang penting bagi suatu daerah. Kecamatan sangat menentukan keberhasilan dalam pelaksanaan tugas yang dilaksanakan oleh instansi pemerintah yang berada diatasnya.

Dimana sekarang ini, kecamatan bukan lagi wilayah administrasi pemerintahan melainkan suatu wilayah dari perangkat daerah. Hal tersebut menjadi kecamatan bukan lagi wilayah kekuasaan akan tetapi merupakan wilayah pelayanan. Sebagai rangkaian kerjasama dalam mencapai tujuan organisasi, dimana seorang administrator adalah mengatur, maka administrasi pemerintah kecamatan yang merupakan bagian dari administrasi publik tidak lepas dari bagaimana mengatur dan menggerakan orang-orang yang ada diwilayah kerjanya untuk sama-sama mensukseskan tujuan organisasi pemerintah kecamatan.

Kecamatan Dusun Tengah Kabupaten Barito Timur, sebagaimana banyak kecamatan lain, juga tidak lepas dari permasalahan mengenai kinerja dalam 
memberikan pelayanan publik. Salah satu aspek yang sangat dicermati oleh masyarakat Kecamatan Dusun Tengah adalah yang berhubungan dengan pelayanan publik, pelayanan publik menjadi salah satu yang paling banyak mendapatkan kritikan dan sorotan dari masyarakat karena dari dahulu sampai sekarang ini masih banyak kepentingan mereka dalam mengurus urusan mereka yang berhubungan dengan pihak penyelenggara pelayanan telah diabaikan seperti halnya program dan kebijakan yang sudah ditetapkan itu mereka selenggarakan sangat tidak sesuai dengan yang kita harapkan dengan kata lain selama itu pelayanan terhadap masyarakat tidak pernah baik

Sehingga berdasarkan uraian di atas peneliti tertarik untuk memilih judul Skripsi mengenai “ Akuntabilitas Pelayanan Publik Di Kantor Camat Dusun Tengah Kabupaten Barito Timur “

\subsection{Rumusan Masalah}

Adapun rumusan masalah yang akan saya ambil dalam penelitian ini yaitu :

1. Bagaimana Akuntabilitas Pelayanan Publik di Kantor Camat Dusun Tengah Kabupaten Barito Timur.

2. Apa faktor penghambat dalam Akuntabilita Pelayanan Publik Di Kantor Camat Dusun Tengah Kabupaten Barito Timur.

\subsection{Tujuan Penelitian}

Tujuan yang ingin dicapai dalam penelitian ini adalah :

1. Untuk menggambarkan dan menganalisa akuntabilitas kinerja pelayanan publik.

2. Untuk mengetahui faktor-faktor yang mempengaruhi dalam pelaksanaan akuntabilitas kinerja pelayanan publik di kantor camat dusun tengah kabupaten barito timur

\subsection{Manfaat Penelitian}

Adapun manfaat dari penelitian ini adalah :

1. Hasil penelitian ini dapat dijadikan sebagai bahan masukan untuk kinerja aparatur pemerintahan dalam pelayanan publik untuk mencapai suatu akuntabilitas dalam kinerjanya.

2. Dengan adanya penelitian ini maka sipeneliti dapat menambah wawasan dan pengetahuanya dalam bidang kepemerintahan.

\section{TINJAUAN PUSTAKA}

\section{Akuntabilitas}

Akuntabilitas merupakan sebuah konsep etika yang dekat dengan administrasi publik pemerintahan yang mempunyai beberapa arti antara lain, hal ini sering digunakan secara sinonim dengan konsep-konsep seperti yang dapat dipertanggungjawabkan Responsibility, yang dapat dipertanyakan Answerability, yang dapat dipersalahkan Blameworthines dan yang mempunyai ketidakbebasan Liability termasuk istilah lain yang memiliki keterkaitan dengan harapan yang dapat menerangkannya salah satu aspek dari administrasi publik atau 
pemerintahan. Dalam peran kepemimpinan, akuntabilitas dapat merupakan suatu pengetahuan dan adanya pertanggungjawaban terhadap tiap tindakan, produk, keputusan dan kebijakan termasuk juga didalamnya administrasi publik pemerintahan, dan pelaksanaan dalam lingkup peran dan posisi kerja yang mencakup didalam mempunyai suatu kewajian untuk melaporkan, menjelaskan dan dapat dipertanyakan bagi tiap-tiap konsekuensi yang sudah dihasilkan.

\section{Akuntabilitas Pelayanan Publik}

Penyelenggaraan pelayanan publik harus dapat dipertanggungjawabkan, baik kepada publik maupun kepada atasan atau pimpinan unit pelayanan instansi pemerintah sesuai dengan ketentuan perundang-undangan. Pertanggungjawaban pelayanan publik yaitu :

1. Akuntabilitas kinerja pelayanan publik

a. Akuntabilitas kinerja pelayanan publik dapat dilihat berdasarkan proses yang antara lain meliputi : tingkat ketelitian, profesionalitas petugas, kelengkapan sarana dan prasarana, kejelasan aturan dan kedisiplinan.

b. Akuntabilitas kinerja pelayanan publik harus sesuai dengan standar, akta atau janji pelayanan publik yang telah ditetapkan.

c. Standar pelayanan publik harus dapat dipertanggungjawabkan secara terbuka, baik kepada publik maupun kepada atasan atau pimpinan unit pelayanan instansi pemerintah. Apabila terjadi penyimpangan dalam hal pencapaian standar, maka harus diupayakan perbaikan.

d. Penyimpangan yang terkait dengan akuntabilitas kinerja pelayanan publik harus diberikan kompensasi kepada penerima pelayanan.

e. Masyarakat dapat melakukan penilaian terhadap kinerja pelayanan secara berkala sesuai dengan mekanisme yang berkalu.

f. Disediakan mekanisme pertanggungjawaban bila terjadi kerugian dalam pelayanan publik, atau pengaduan masyarakat tidak mendapat tanggapan sesuai dengan waktu yang telah ditentukan.

2. Akuntabilitas biaya pelayanan publik

a. Biaya pelayanan dipungut sesuai dengan ketentuan peraturan perundangundangan yang telah ditetapkan.

b. Pengaduan masyarakat terkait penyimpangan biaya pelayanan publik, harus ditangani oleh petugas yang ditunjuk berdasarkan surat keputusan atau surat penugasan dari pejabat yang berwenang.

3. Akuntabilitas produk pelayanan publik

a. Persyaratan dan assminitratif harus jelas dan dipertanggungjawabkan dari segi kualitas dan keabsahan produk pelayanan.

b. Prosedur dan mekanisme kerja harus sederhana dan dilaksanakan sesuai dengan ketentuan yang telah diharapkan.

c. Produk pelayanan diterima dengan benar, tepat dan sah.

\section{Dampak Adanya Akuntabilitas}

Dampak adanya akuntabilitas adalah meningkatnya kepercayaan masyarakat terhadap pemerintah, sehingga kredibilitas pemerintahan yang diakui dan 
keberadaannya akan selalu didambakan. Hal itu menyebabkan masyarakat ikut peduli dan memberikan suatu partisipasi dalam setiap program pemerintahan. Akan tetapi dalam prakteknya untuk menjalankan asas akuntabilitas, seringkali mengalami hambatan-hambatan dan hal yang dapat menghambat dari akuntabilitas.

\section{Pelayanan Publik}

Pemerintah sebagai abdi masyarakat atau negara memiliki fungsi utama untuk mengadakan dan memberikan pelayanan pada masyarakat dengan baik dan memuaskan. Sifat yang paling menonjol dan administrasi adalah bersifat pelayanan dengan tujuan membantu pekerjaan organisasi secara keseluruhan. Menurut Herbani Pasolong (2011 : 28) dimaksud dengan proses pelayanan adalah proses pemenuhan kenutuhan melalui aktivitas orang lain secara langsung yang ada pada hakekatnya merupakan serangkaian kegiatan. Oleh karena itu peleyanan merupakan suatu proses pelayanan yang berlangsung secara rutin dengan meliputi seluruh kehidupan masyarakat. pelayanan publik adalah suatu usaha yang dilakukan oleh seseorang atau sekelompok orang atau instansi tertentu untuk memberikan bantuan dan kemudahan kepada masyarakat atau kelompok yang dilayani dalam rangka untuk memenuhi kebutuhan masyarakat akan pelayanan. Pelayanan ini harus diberikan kepada seluruh masyarakat atau yang berhak untuk mendapatkan pelayanan tanpa terkecuali dengan tidak membedakan antara satu dengan yang lainya.

\section{METODE PENELITIAN}

\section{Jenis Penelitian}

Menurut bogdan dan Taylor dalam Margono (2007:36) Jenis penelitian yang akan digunakan dalam penelitian ini adalah penelitian deskriptif dengan metode pendekatan kualitatif. Penelitian deskriptif kualitatif adalah prosedur penelitian yang menghasilkan data deskriptif berupa kata-kata tertulis atau lisan dari orangorang dan perilaku yang dapat diamati.

Sedangkan menurut Sugiono (2013:9) metode penelitian kualitatif adalah metode yang berdasarkan pada falsafah postposititivisme, digunakan untuk meneliti pada kondisi objek yang alamiah ( sebagai lawannya adalah eksperimen ) dimana peneliti adalah instrumen kunci, teknik pengumpulan data dilakukan secara triagulasi, analisis data bersifat induktif atau kualitatif, dan hasil penelitian kualitatif lebih menekankan makna dari pada generalisasi.

Dengan demikian dapat disimpulkan bahwa penelitian ini adalah penelitian yang penyajian datanya dilakukan dan disampaikan dengan menggambarkan fenomena sesuai dengan objek yang diteliti secara sistematis berdasarkan data dan fakta dilapangan.

Oleh karena itu dalam penelitian ini digunakan metode deskriptif -kualitatif untuk mendeskripsikan Akuntabilitas Kinerja Pelayanan Publik Di Kantor Camat Dusun Tengah Kabupaten Barito timur. 


\section{Lokasi Penelitian}

Penelitian ini dilaksanakan di Kantor camat Dusun Tengah Kabupaten Barito Timur. Karena kantor kecamatan merupakan wadah terdapat adanya beberapa hal yang ada kaitannya dengan pelaksanaan akuntabilitas dan mengenai masalah kinerja pegawai dalam memberikan pelayanan publik, peneliti sering berkomunikasi dengan staf-staf yang ada pada lokasi penelitian sehinggasangat memudahkan dalam proses penelitian dan harapan mampu memberikan masukan, saran dan poin tersendiri kepada peneliti atau sebaliknya.

\section{Fokus Penelitian}

Dengan adanya arahan suatu fokus penelitian, maka dalam penelitian ini yang menjadi fokusnya adalah :

1. Akuantabilitas Pelayanan Publik Di Kantor Kecamatan Dusun Tengah Kabupaten Barito Timur dapat dilihat dari:

a. Prosedur Pelayanan di Kantor Camat Dusun Tengah.

b. Akuntabilitas terhadap kinerja Pelayanan Publik.

2. Faktor yang mempengaruhi pelaksanaan akuntabilitas pelayanan publik dapat kita lihat dari:
a. Tingkat Pendidikan.
c. Faktor Lingkungan.
c. Masa Kerja Pegawai

\section{Sumber Data}

Semua data yang diperoleh melalui sumber data merupakan informasi yang dapat dijadikan nara sumber data, karena dianggap menguasai bidang permasalahan dan berhubungan erat dengan pelaksanaan seluruh kegiatan untuk mempermudah penyelesaian masalah dalam penelitian. Jenis sumber data yang digunakan dapat dibedakan menjadi dua bagian yaitu :

1. Data Primer

2. Data Sekunder

\section{Teknik Pengumpulan Data}

Dalam melakukan pengumpulan data, dilakukan tiga teknik pengumpulan data yaitu :

1. Observasi

2. Wawancara

3. Dokumentasi

\section{Analisa Data}

Menurut Miles dan Huberman dalam Sugiono ( 2008 : 345 ) mengemukakan bahwa aktivitas dalam analisis data kualitatif dilakukan secara interaktif dan berlangsung secara terus menerus sampai tuntas, sehingga datanya sudah jenuh. Aktivitas dalam analisis data, yaitu :
1. Reduksi Data
2. Penyajian Data 


\section{Penarikan Kesimpulan}

\section{HASIL DAN PEMBAHASAN}

Untuk mempermudah proses pelayanan maka diperlukan suatu aturan yang jelas yang tertuang pada prosedur yang berlaku dalam instansi tersebut. Prosedur pelayanan yang tidak terlalu panjang dan mudah sangat dihapkan oleh pengguna jasa pelayanan. Pada Kantor Camat Dusun Tengah prosedur pelayanan yang diberikan sesuai pada aturan yang berlaku. Prosedur pelayanan yang ada di Kantor Camat Dusun Tengah dapat dilihat persyaratan dan tata cara pelayanan serta ketepatan waktunya.

\section{Akuntabilitas Pelayanan Publik}

Dusun Tengah Mandiri Yang Berbasis Swasembada Pangan Dan Perdagangan adalah misi dari Kantor Camat Dusun Tengah. Oleh karena itu mengutamakan prioritas utama bagi pelayanan yang telah diberikan oleh pihak kecamatan. Semua tugas dan kewajiban yang menyangkut pelayanan terhadap publik menjadi tanggung jawab setiap pegawai di Kantor Camat Dusun Tengah. Dengan terdapatnya suatu produk yang dihasilkan oleh instansi pada tingkat kecamatan. Yang dimana mutu dari produk yang telah dihasilkan itu tergaantung dengan tingkat kepuasan publik yang dipengaruhi oleh baik buruknya suatu kinerja dalam memberikan pelayanan kepada masyarakat.

Selain peningkatan pelayanan melalui kinerja yang terkoordinasi dan melalui pelayanan prima, maka misi lain yang terdapat pada Kantor Camat Dusun Tengah adalah terciptanya informasi-informasi tentang data-data yang ada di Kantor Camat Dusun Tengah yang didasarkanpada informasi manajemen pada masing-masing bidang. Mengingat begitu besarnya tugas yang telah diterima oleh kantor Kecamatan Dusun Tengah, maka sangatlah wajar jika instansi pemerintahan pada tingkat kecamatan melakukan dan diwajibkan untuk menjalankan akuntabilitas terhadap publik. Olehh karena itu, tugas-tugas yang diemban oleh kecamatan merupakan tugas yang menyangkut kehidupan, kepentingan bangsa, negara dan masyarakat.

\section{Pembahasan}

\section{Analisa Terhadap Akuntabilitas Pelayanan Publik di Kantor Camat Dusun Tengah}

Berdasarkan hasil wawancara dengan para pegawai di Kantor Camat Dusun Tengah. Maka dapat kita ketahui dilakukannya akuntabilitas adalah untuk menjaga suatu kepercayaan masyarakat dan untuk mempertanggungjawabkan kewenangan yang diterimanya kepada pihak yang lebih tinggi atau yang lebih berwenang.

Dilihat dari alasan tersebut peneliti menganggap bahwa pelaksanaan akuntabilitas tersebut sangat diperlukan. Begitu juga apabila dilihat dari hirarki kewenangan yang ada pada Kantor Camat Dusun Tengah maka proses akuntabilitas yang ada akan berjalan seperti masing-masing pegawai bertanggungjawab kepada kepala kasinya masing-masing kemudian kasinya akan 
bertanggungjawab kepada camat. Begitu juga dengan manfaat akuntabilitas yang dilakukan oleh Kantor Camat Dusun Tengah dimana akuntabilitas tidak dibuat pada kegiatan sehari-hari dalam memberikan suatu pelayanan kepada publik, tetapi jika hanya mendapat tugas yang mewajibkan pihak kantor camat dusun tengah untuk membuat laporan akuntabilitas.

\section{Akuntabilitas Pelayanan Publik}

Keberadaan akuntabilitas dalam organisasi sangatlah vital, karena akuntabilitas merupakan perwujudan untuk mempertanggungjawabkan dan menerangkan kinerja dan tindakan seseorang atau pimpinan suatu organisasi kepada pihak yang memiliki hal dan kewenangan untuk meminta keterangan atau akuntabilitas atas keberhasilan atau kegagalan pelaksanaan misi dalam pencapaian organisasi. Jika melihat dari apa yang sudah diterangkan maka keberadaan akuntabilitas memiliki manfaat yang cukup besar untuk meningkatkan suatu kinerja dengan harapan agar dalam kinerja memiliki tanggungjawab pada tugas dan fungsinya masing-masing. Akuntabilitas dapat mempengaruhi pola kinerja dalam menjalankan tugas dan kewenangan yang diemban targantung sejauh mana akuntabilitas tersebut dijalankan.

Jika melihat dari hasil wawancara dan pengamatan langsung yang dilakukan, peneliti menyimpulkan bahwa akuntabilitas yang dilaksanakan pada Kantor Camat Dusun Tengah memiliki pengaruh yang relatif kecil,karena pada Kantor Camat Dusun Tengah, akuntabilitas dibuat tidak untuk mengevaluasi kinerja dalam memberikan suatu pelayanan kepada publik sebagaimana tugas yang dilakukakan dalam sehari-hari, tetapi bila Kantor Camat Dusun Tengah mendapat tugas dari instansi yang berada diatasnya untuk melakukan suatu kegiatan kegiatan dalam kurun waktu tertentu.

Hal ini menyebabkan keberadaan akuntabilitas dipandang sebatas laporan kegiatan saja tanpa melihat manfaatnya saja sebenarnya dari akuntabilitas itu sendiri. Keberadaan akuntabilitas di Kantor Camat Dusun Tengah tidak terlalu berpengaruh dalam merobah pola kinerja dalam memberikan suatu pelayanan kepada publik sehingga pelayanan yang diberikan dari waktu kewaktu relatif sama tanpa ada perubahan seperti yang diinginkan oleh masyarakat.

\section{Faktor-Faktor Yang Mempengaruhi Akuntabilitas Kinerja Pelayanan Publik}

Mengenai faktor-faktor yang mempengaruhi proses akuntabilitas kinerja pelayanan publik pada Kantor Camat Dusun Tengah seperti yang dapat kita lihat pada data yang ada ialah pada tingkat pendidikan, budaya kinerja, pengaruh lingkungan dan masa kerja pegawai. Pertama adalah pada faktor tingkat pendidikan pegawai sangat mempengaruhi mengenai pemahaman pegawai dalam melaksanakan kinerjanya sesuai dengan tugasnya. Dengan tingkat pendidikan yang tinggi maka pemahaman atas pentingnya penerapan konsep akuntabilitas dalam menjalankan suatu kinerjanya dan juga akan semakain baik sehingga mempercepat pula peningkatan dalam kinerja memberikan pelayanan kepada publik.

Tekanan dari lingkungan serta budaya kinerja merupakan gambaran pola kinerja suatu organisasi.Seperti yang dikemukakan oleh Agus suryono (2001 : 5) 
yaitu : tekanan dari lingkungan, dimana faktor lingkungan sangat mempengaruhi kinerja organisasi pelayanan dalam transaksi dan interaksinya antara lingkungan dan organisasi publik, sedangkan budaya kinerja dalam organisasi penyelenggaraan pelayanan publik di Indonesia masih terkait oleh tradisi politik dan budaya masyarakat setempat yang sering tidak kondusif dan melanggar peraturan yang telah ditetapkan.

Sesuai dengan konsep yang dikemukakan diatas, maka pengaruh lingkungan suatu kinerja dapat mempengaruhi suatu kinerja yang ada pada akhirnya akan berdampak pada kualitas akuntabilitas pada diri sendiri, atas maupun masyarakat. Budaya kerja yang baik akan berpengaruh pula pada suatu kinerja. Karena jika dalam suatu organisasi tersebut telah tertanam tanggungjawab akan kewenangan yang diemban maka mutu dari kinerja dapat dijamin kualitasnya dengan kinerja yang baik maka proses akuntabilitas yang baik dan dapat dilaksanakan.

Kemudian faktor yang terakhir adalah masa kerja pegawai. Terdapatnya beberapa pegawai dengan masa kerja yang relatif minim menjadikan penyebab kurangnya pemahaman tentang manfaat akuntabilitas untuk merubah kinerja agar menjadi lebih baik. Akan tetapi terdapatnya tenaga kerja dengan pengalaman masa kerja pegawai yang dianggap banyak diharapkan dapat membimbing para pegawai yang memiliki masa kerja yang masih relatif minim. Perlunya peningkatan pemahaman pentingnya akuntabilitas dalam suatu organisasi akan lebih baik bila dimulai sejak dini. Selain itu dibutuhkan sosialisasi secara berkala terhadap pola kinerja yang berdasarkan atas akuntabilitas yang menjadikan pemahaman terhadap akuntabilitas dapat ditingkatkan seiring berjalannya masa kerja pegawai.

\section{PENUTUP}

\section{Kesimpulan}

Dari penyajian data dan analisa data yang telah peneliti lakukan, maka peneliti menggambil kesimpulan sebagai berikut :

1. Sebagaimana yang sudah kita ketahui bahwa akuntabilitas pelayanan publik yang dilaksanakan oleh kantor camat dusun tengah bisa dikatakan cukup baik, karena dalam alur proses pelayanan yang telah mereka berikan itu sudah jelas dengan tidak berbelit-belit. Akuntabilitas pelayanan publik di kantor camat dusun tengah juga dilakukan demi meningkatkan kepercayaan masyarakat agar dalam runang lingkup pelayanan bisa berjalan sesuai dengan keinginan yang akan dicapai.

2. Faktor yang menghambat akuntabilitas pelayanan publik di kantor camat dusun tengah sebagaimana yang kita ketahui ada beberapa faktor yaitu sumberdaya manusia yang dimiliki oleh pegawai, dimana pengetahuan tentang pentingnya penanaman jiwa yang akuntabel dalam diri pegawai sangat kurang, tingkat kedisiplinan sangat kurang akan tetapi hal tersebut tergantung dengan budaya kerja yang dia miliki, faktor lingkungan juga memuliki pengaruh yang tidak sedikit dari proses akuntabilitas itu sendiri. Dengah adanya hal tersebut maka menjadikan suatu pelayanan kurang optimal. 


\section{Saran}

Adapun saran yang telah peneliti berikan yaitu :

1. Camat selaku pimpinan diwilayah kerjanya harus melihat kelebihan dan kekurangan dalam proses-proses akuntabilitas pelayanan publik agar bisa terselenggara dengan baik

2. Camat dapat membuat suatu terobosan untuk merobah pola/ sistem pelayanan dengan membuat suatu kebijakan untuk membantu para pegawai dalam bekerja atau dalam menjalankan tugasnya dengan membuat ukuran-ukuran dalam pelayanan yang harus dilaksanakan dengan baik

3. Camat maupun pegawai yang ada di Kantor Camat Dusun Tengah lebih memperhatikan kepentingan masyarakat sebagai pengguna jasa yang harus dilayani.

\section{DAFTAR PUSTAKA}

Beratha, I Nyoman. 1992. Desa, Masyarakat Desa, dan Pembangunan. Jakarta: Ghalia Indonesia.

ejournal.pin.or.id/site/wp.../EJURNAL\%20(02-27-13-11-34-51).pdf,diakses tanggal 16 Juli 2014.

Hatake, Ogenk. Skripsi. 2011. Upaya Peningkatan Kemampuan Aparat Desa dalam Pelaksanaan Tugas Administrasi Pemerintah Desa di Desa Watusa Kecamatan Kecamatan Puriala di Kabupaten Konawe. Konawe: Universitas Tadulako.

Mulyana, Nana dkk. Jurnal Ilmu Administrasi Negara. 2012. Peningkatan Kapasitas Aparatur Pemerintah Desa Melalui Pelatihan Manajemen Kelembagaan Desa Bagi Sekretaris Desa. Lampung: Seminar Hasil-Hasil Penelitian dan Pengabdian Masyarakat.

Pasolong, Harbani. 2007. Teori Administrasi Publik. Bandung: Alfabeta.

Peraturan Menteri Dalam Negeri Nomor 32 Tahun 2006 tentang Pedoman Administrasi Desa.

Peraturan Pemerintah Republik Indonesia Nomor 72 Tahun 2005 tentang Desa.

Rasyid, M. 1992. Pembangunan Kualitas dan Usaha-Usaha Peningkatan Aparatur Pemerintah. Palu: Universitas Tadulako

Riduwan dan Sunarto. 2009. Pengantar Statistika Untuk Penelitian. Bandung: Alfabeta.

Saparin, Sumber. 1996. Tata Pemerintahan dan Administrasi Pemerintahan Desa. Jakarta: Ghalia Indonesia.

Siagian, SP. 1991. Administrasi Pembangunan. Jakarta: Haji Masagung. 
Singarimbun, Masri, dan Effendi, Sofian. 1995. Metode Penelitian Survei. Jakarta: PT. Pustaka LP3ES.

Sudarmanto. 2009. KINERJA dan PENGEMBANGAN KOMPETENSI SDM, Teori, Dimensi Pengukuran, dan Implementasi Organisasi.Yogyakarta: Pustaka Pelajar

Sugiyono. 2005. Metode Penelitian Administrasi. Bandung: Alfabeta.

Sugiyono. 2010. Metode Penelitian Administrasi. Bandung: Alfabeta.

Syarif, Roesli. 1991. Teknik Manajemen Latihan dan Pembinaan. Bandung: Bina Aksara.

Tjiptoherianto, Prijono. 1993. Pembangunan Sumber Daya Manusia. Jakarta: Prisma.

Undang-Undang Republik Indonesia Nomor 32 Tahun 2004 tentang Pemerintah Daerah. 